\title{
Diagnostic Value of Fine Needle Aspiration Cytology in Testicular Disorders of Red Deer (Cervus elaphus): A Case Report
}

Source: Journal of Wildlife Diseases, 50(4):994-997.

Published By: Wildlife Disease Association

URL: http://www.bioone.org/doi/full/10.7589/2013-11-304

BioOne (www.bioone.org) is a nonprofit, online aggregation of core research in the biological, ecological, and environmental sciences. BioOne provides a sustainable online platform for over 170 journals and books published by nonprofit societies, associations, museums, institutions, and presses.

Your use of this PDF, the BioOne Web site, and all posted and associated content indicates your acceptance of BioOne's Terms of Use, available at www.bioone.org/page/ terms of use.

Usage of BioOne content is strictly limited to personal, educational, and non-commercial use. Commercial inquiries or rights and permissions requests should be directed to the individual publisher as copyright holder. 


\title{
Diagnostic Value of Fine Needle Aspiration Cytology in Testicular Disorders of Red Deer (Cervus elaphus): A Case Report
}

\begin{abstract}
Eliana Pintus, ${ }^{1,2,5}$ José Luis Ros-Santaella, ${ }^{3,4}$ and José Julián Garde ${ }^{3}{ }^{1}$ Department of Pathology and Veterinary Clinic, University of Sassari, Via Vienna 2, 07100 Sassari, Italy; ${ }^{2}$ Department of Veterinary Sciences, Faculty of Agrobiology, Food and Natural Resources, Czech University of Life Sciences, Kamýcká 129, 16521 Prague 6 - Suchdol, Czech Republic; ${ }^{3}$ SaBio IREC (CSIC-UCLM-JCCM), Campus Universitario s. n. 02071 Albacete, Spain; ${ }^{4}$ Department of Animal Science and Food Processing, Faculty of Tropical AgriSciences, Czech University of Life Sciences, Kamýcká 129, 16521 Prague 6 - Suchdol, Czech Republic; ${ }^{5}$ Corresponding author (email: eliana.pintus@ virgilio.it)
\end{abstract}

ABSTRACT: We used fine needle aspiration cytology (FNAC) to diagnose Sertoli cell-only pattern and hypospermatogenesis in an Iberian red deer (Cervus elaphus hispanicus). Cytologic diagnosis was confirmed by histology and epididymal sperm analysis. We conclude that FNAC can be an important diagnostic tool in testicular diseases of wildlife.

Assessment of spermatogenesis plays a key role in the evaluation of male fertility. Although several methods have been described, fine needle aspiration cytology (FNAC) is currently the simplest and least-invasive technique for obtaining testicular samples (e.g., Gouletsou et al. 2012). Developed by Posner and Cohn (1904) as a diagnostic tool in human infertility, FNAC has been applied in veterinary medicine only recently (e.g., Romagnoli et al. 2009).

Several studies report testicular disorders in cervids including white-tailed deer (Odocoileus virginianus; Taylor et al. 1964), black-tailed deer (Odocoileus hemionus; Tiller et al. 1997; Odocoileus hemionus columbianus; DeMartini and Connolly 1975; Odocoileus hemionus sitkensis; Bubenik et al. 2001), red deer (Cervus elaphus; Carrasco et al. 1997), and pampas deer (Ozotoceros bezoarticus, Ungerfeld 2013). We describe the diagnosis of Sertoli cellonly pattern and hypospermatogenesis by FNAC in an Iberian red deer (Cervus elaphus hispanicus).

An adult Iberian red deer (age $>4.5 \mathrm{yr}$, body mass $>130 \mathrm{~kg}$ ) was culled in February (nonbreeding season) 2011 in Spain in accordance with Spanish harvest regulations. Testes, within the scrotal sac, were transported to the laboratory at 20-25 C and processed 4-8 hr postmortem. The testes were descended into the scrotal sac and, together with epididymides, exhibited normal consistency. Macroscopic analysis revealed no abnormality except for marked testicular asymmetry. Testicular mass was $48.10 \mathrm{~g}$ and $34.26 \mathrm{~g}$ in the right and left testes, respectively. Mean $( \pm S D)$ testicular masses in stags culled at the same date and location were similar between the left and right testes (44.92 $46.85 \mathrm{~g}$ and $42.09 \pm 7.05 \mathrm{~g}$, respectively; $P=0.221$, paired $t$-test, $t=1.396$, $\mathrm{df}=5, n=6)$.

Cytologic and histologic analyses were performed as described by Pintus et al. (2014). Briefly, a 20-G needle, connected to a 5 -mL syringe, was inserted into the testis avoiding the epididymis. After gentle in-out movements, the content was flushed onto a glass slide and smeared. Smears were air-dried and stained with Hemacolor ${ }^{\circledR}$ (Merck, Darmstadt, Germany). Percentages of spermatogenic cells and cytologic indices were determined on at least 200 spermatogenic and Sertoli cells as follows (Pintus et al. 2014): the Sertoli cell index (SEI) was the number of Sertoli cells per 100 spermatogenic cells as an index of spermatogenic activity; spermatic index (SI) was the number of spermatozoa per 100 spermatogenic cells as an index of spermiogenic activity; spermatozoa-Sertoli index (SSEI) was the number of spermatozoa per Sertoli cell; Sptd ab:sptc I was the number of round spermatids per primary spermatocyte as an index of meiotic activity; and number of 


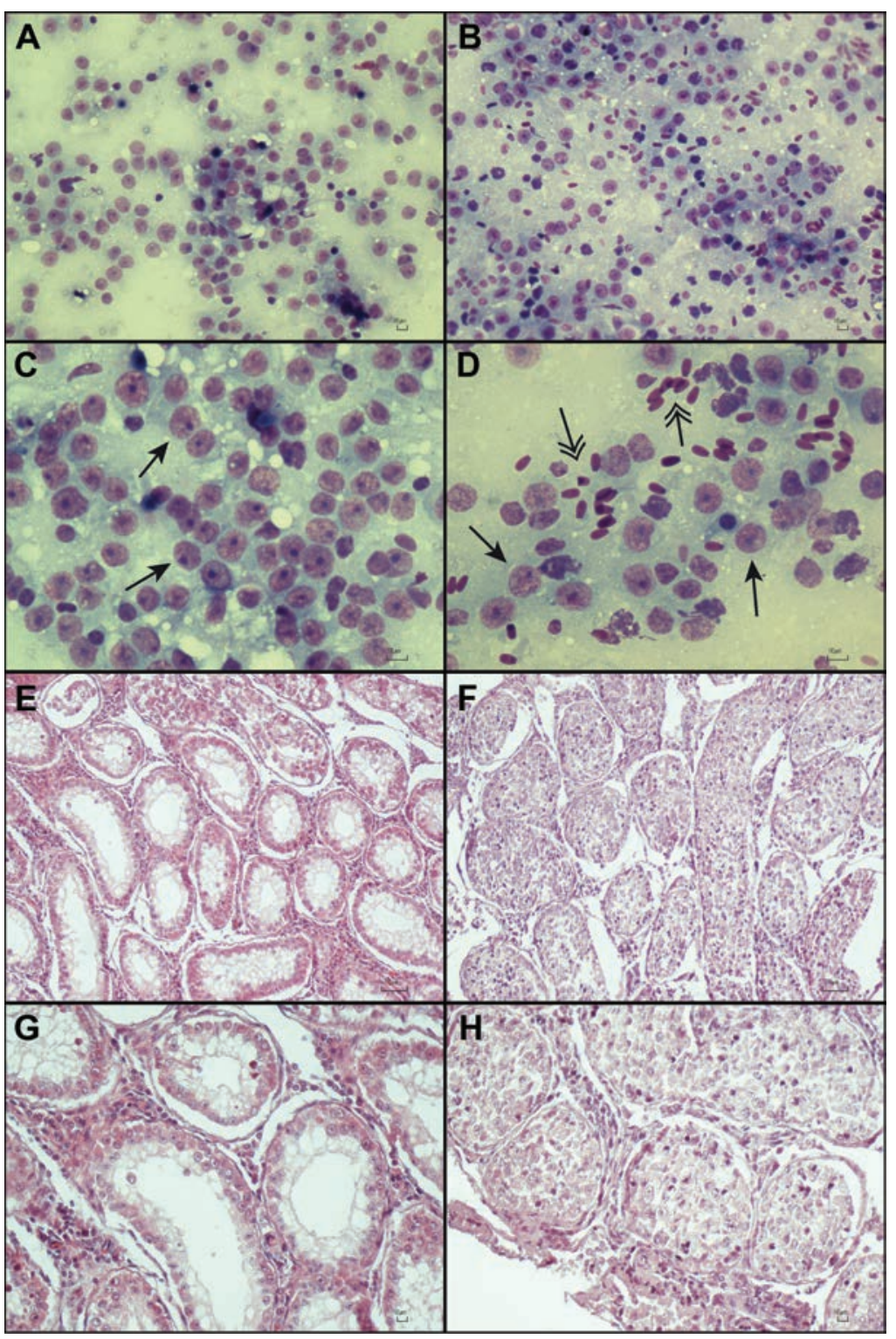

Figure 1. Testicular cytology and histology from Iberian red deer (Cervus elaphus hispanicus) affected by spermatogenic disorders. Aspermatogenesis and Sertoli cell-only pattern were found in the left testis (left column); hypospermatogenesis was found in the right testis (right column). (A) Cytologic feature of aspermatogenesis. Note the low cellularity represented by the Sertoli cell-only pattern. Bar $=10 \mu \mathrm{m}$. (B) Cytologic feature of hypospermatogenesis showing moderate cellularity represented both by germ cells and Sertoli cells. Bar $=10 \mu \mathrm{m}$. (C) Sertoli cell-only pattern at higher magnification. Sertoli cells (arrows) usually appear as naked nuclei with finely granular chromatin and a single, clearly visible nucleolus. Bar $=10 \mu \mathrm{m}$. (D) Germ cells (double arrows) and Sertoli cells (single arrows) at higher magnification. Bar $=10 \mu \mathrm{m}$. (E) Histologic feature of Sertoli cell-only tubules (H\&E). Interstitial tissue appeared normal and no signs of inflammatory infiltrate or fibrosis were detected. Bar $=50 \mu \mathrm{m}$. (F) Histologic feature of hypospermatogenesis $(\mathrm{H} \& \mathrm{E}) . \mathrm{Bar}=50 \mu \mathrm{m}$. (G) Histologic feature of Sertoli cell-only at higher magnification $(\mathrm{H} \& \mathrm{E}) . \mathrm{Bar}=10 \mu \mathrm{m}$. (H) Histologic feature of hypospermatogenesis at higher magnification $(\mathrm{H} \& \mathrm{E})$. Bar $=10 \mu \mathrm{m}$. 
TABLE 1. Sperm parameters of an Iberian red deer (Cervus elaphus hispanicus) affected by testicular disorders and control values from Iberian red deer $(n=6)$ with normal spermatogenesis culled on the same date in Spain.

\begin{tabular}{lccc}
\hline & Iberian red deer with & & Iberian red deer with normal spermatogenesis \\
\cline { 3 - 4 } \multicolumn{1}{c}{ Parameter $^{\mathrm{b}}$} & Rypospermatogenesis & Mean \pm SD & Range \\
\hline Sperm concentration $\left(\times 10^{6} / \mathrm{mL}\right)^{\mathrm{c}}$ & 656 & $1,872 \pm 923$ & $766-3,144$ \\
Total sperm number $\left(\times 10^{6}\right)$ & 261 & $1,052 \pm 673$ & $292-2,101$ \\
Viability $(\%)^{\mathrm{d}}$ & 83.05 & $55.80 \pm 8.55$ & $44.51-67.27$ \\
Total motility $(\%)^{\mathrm{e}}$ & 99.62 & $78.50 \pm 23.92$ & $34.82-99.92$ \\
Progressive motility $(\%)$ & 12.73 & $10.76 \pm 5.04$ & $1.02-14.79$ \\
VAP $(\mu \mathrm{m} / \mathrm{sec})$ & 86.11 & $46.25 \pm 25.57$ & $9.88-81.32$ \\
VSL $(\mu \mathrm{m} / \mathrm{sec})$ & 47.83 & $25.07 \pm 12.78$ & $5.77-43.20$ \\
VCL $(\mu \mathrm{m} / \mathrm{sec})$ & 138.30 & $63.34 \pm 32.53$ & $19.80-113.04$ \\
LIN $(\%)$ & 34.15 & $37.06 \pm 4.75$ & $28.62-41.37$ \\
STR $(\%)$ & 54.99 & $56.40 \pm 3.02$ & $52.30-60.48$ \\
WOB $(\%)$ & 61.16 & $65.61 \pm 8.85$ & $50.10-74.65$ \\
ALH $(\mu \mathrm{m})$ & 5.60 & $2.48 \pm 0.98$ & $1.29-4.15$ \\
BCF $(\mathrm{Hz})$ & 6.71 & $4.97 \pm 1.58$ & $2.39-7.13$ \\
\hline
\end{tabular}

${ }^{\text {a }} \mathrm{VAP}=$ average path velocity; VSL $=$ straight linear velocity; VCL $=$ curvilinear velocity; LIN $=$ linearity; STR $=$ straightness; WOB = wobble (VAP/VCL); ALH = lateral head displacement; BCF = beat cross frequency.

${ }^{\mathrm{b}}$ Values refer to the content of both epididymides.

c Sperm concentration was evaluated using a Makler chamber.

${ }^{\mathrm{d}}$ Sperm viability was evaluated by flow cytometry (propidium iodide/YO-PRO ${ }^{\circledR}-1$, Invitrogen, Barcelona, Spain).

e Sperm motility was assessed by Sperm Class Analyzer (SCA, Microptic S.L., Barcelona, Spain).

germ cells per Sertoli cell (GC:SC) was assessed as an index of Sertoli cell workload. Histologic samples were analyzed according to the Johnsen (1970) score.

Findings for testicular cytology and histology are illustrated in Figure 1. Analysis of the left testis revealed low cellularity represented by a Sertoli cell-only pattern (SEI: 100; Fig. 1A). Sertoli cells exhibited normal morphology (Fig. 1C). Data were confirmed by histology showing that Sertoli cells were the only cells per tubular cross-section (Johnsen score: 2.02; Fig. 1E, G). No sperm sample was recovered from the epididymal cauda.

Smears from the right testis showed both spermatogenic and Sertoli cells (Fig. 1B, D). Percentages of spermatogenic cells were $3.27 \%$ spermatogonia, $20.91 \%$ primary spermatocytes, $15.03 \%$ round spermatids, and $57.52 \%$ elongated spermatids. Secondary spermatocytes were not observed due to their short lifespan (Leme and Papa 2010). The SI and SSEI were much lower (3.27 and 0.09, respectively) than normal values (mean $\pm S D, \quad S I$ :
16.13 \pm 5.49 ; SSEI: $1.67 \pm 0.79 ; n=6)$. Conversely, SEI was higher than normal values (35.29 vs. 11.74 \pm 5.90$)$ whereas Sptd $\mathrm{ab}:$ sptc I and GC:SC ratios were low $(0.72$ vs. $2.21 \pm 0.48$ and 2.83 vs. 6.94 23.37 , respectively). Although histologic sections were not optimal due to the delay of testes fixation, tubules showed no lumen, with few spermatozoa or only spermatids (Fig. 1F, H). Both cytologic and histologic data from the right testis were indicative of hypospermatogenesis. However, the Johnsen score was similar to the normal value of the same period ( 7.78 vs. $7.69 \pm 0.26 ; n=4$ ). Sperm samples were recovered from the epididymal cauda. Although sperm concentration of the abnormal testis was low, sperm viability and motility were within the range or even higher than normal values (Table 1).

Possible etiologies of hypogonadism include an inflammatory process, vascular obstruction, heat stress, toxicants, nutritional deficiency, poisonous plants, and congenital aplasia, among others (Carrasco et al. 1997; Tiller et al. 1997). We discarded 
an infectious or inflammatory process due to the lack of inflammatory infiltrate or connective tissue replacement. Poisonous plants may induce testicular hypogonadism in deer with lesions that are usually bilateral and affect several individuals within the same population (Taylor et al. 1964). Differentiation of testicular atrophy from congenital aplasia is extremely difficult in the absence of data regarding antler history (Carrasco et al. 1997), as in our case. Ischemia determines testicular atrophy with Sertoli cell-only pattern (Young et al. 1988) and affects spermatogenesis even in the contralateral testis (Sukhotnik et al. 2005). Thus, hypogonadism might be a consequence of a traumatic or vascular obstruction which is also affecting the contralateral testis. Although sperm quality was within or above the normal values, sperm production was low as a consequence of the reduced spermatogenic efficiency. Low efficiency of spermatogenesis together with high Sertoli cells:germ cells ratio characterize testicular degeneration (Papa and Leme 2002). However, a major limitation of this case report is the lack of follicle stimulating hormone, testosterone, and inhibin B blood levels in order to confirm our diagnosis. In conclusion, FNAC is an important diagnostic tool in testicular diseases of wildlife.

Eliana Pintus and José Luis Ros-Santaella are supported by grants CIGA 20145001 and 99830/1181/1822 (Czech University of Life Sciences). We acknowledge Stefania Uccheddu, Mari Cruz Sotos Luna, Alvaro Domínguez-Rebolledo, Enrique Del Olmo, Zandra Maulen, Alfonso Bisbal, Maria del Rocío Fernández-Santos, Ana Josefa Soler, and staff of the Department of Pathology and Veterinary Clinic of the University of Sassari for their assistance.

\section{LITERATURE CITED}

Bubenik GA, Jacobson JP, Schams D, Bartoš L. 2001. Cryptorchism, hypogonadism and antler malformations in black-tailed deer (Odocoileus hemionus sitkensis) of Kodiak Island. Z Jagdwiss 47:241-252.

Carrasco L, Fierro Y, Sánchez-Castillejo JM, Hervás J, Pérez J, Gómez-Villamandos JC. 1997. Abnormal antler growth associated with testicular hypogonadism in red deer. J Wildl Dis 33:670-672.

DeMartini JC, Connolly GE. 1975. Testicular atrophy in Columbian black-tailed deer in California. J Wildl Dis 11:101-106.

Gouletsou PG, Galatos AD, Sideri AI, Kostoulas P. 2012. Impact of fine needle aspiration (FNA) and of the number of punctures on the feline testis: Clinical, gross anatomy and histologic assessment. Theriogenology 78:172-181.

Johnsen SG. 1970. Testicular biopsy score count-A method for registration of spermatogenesis in human testes: Normal values and results in 335 hypogonadal males. Hormones 1:2-25.

Leme DP, Papa FO. 2010. How to perform and interpret testicular fine needle aspiration in stallions. J Equine Vet Sci 30:590-596.

Papa FO, Leme DP. 2002. Testicular fine needle aspiration cytology from a stallion with testicular degeneration after external genitalia trauma. $J$ Equine Vet Sci 2:121-124.

Pintus E, Ros-Santaella JL, Garde JJ. 2014. Variation of spermatogenic and Sertoli cell number detected by fine needle aspiration cytology (FNAC) in Iberian red deer during and out of breeding season. Reprod Fertil Dev. doi: http://dx.doi.org/ 10.1071/RD13419. Accessed May 2014.

Posner C, Cohn J. 1904. Zur diagnose und behandlung der azoospermie. Deut Med Wochenschr 29:1062-1064.

Romagnoli S, Bonaccini P, Stelletta C, Garolla A, Menegazzo M, Foresta C, Mollo A, Milani C, Gelli D. 2009. Clinical use of testicular fine needle aspiration cytology in oligozoospermic and azoospermic dogs. Reprod Dom Anim 44:329-333.

Sukhotnik I, Miselevich I, Lurie M, Nativ O, Coran AG, Mogilner JG. 2005. The time relationship between ipsilateral testicular ischemia and germ cell apoptosis in the contralateral testis in rat. Pediatr Surg Int 21:512-516.

Taylor DO, Thomas JW, Marburger RG. 1964. Abnormal antler growth associated with hypogonadism in white-tailed deer in Texas. Am J Vet Res 25:179-185.

Tiller BL, Dagle GE, Cadwell LL. 1997. Testicular atrophy in a mule deer population. $J$ Wildl Dis 33:420-429.

Ungerfeld R. 2013. Treatment with an equine chorionic gonadotrophin single dose restored spermatozoa production in an azoospermic pampas deer (Ozotoceros bezoarticus) male: A case report. Reprod Med Biol 12:65-68.

Young GP, Goldstein M, Phillips DM, Sundaram K, Gunsalus GL, Bardin CW. 1988. Sertoli cell-only syndrome produced by cold testicular ischemia. Endocrinology 122:1074-1082.

Submitted for publication 21 November 2013.

Accepted 7 April 2014. 